УДК 657.6

DOI: https://doi.org/10.26642/jen-2021-1(95)-39-44

\author{
Я.О. Ізмайлов, д.е.н., проф. \\ Університет державної фіскальної служби Украӥни \\ С.В. Свірко, д.е.н., проф. \\ Державний університет «Житомирська політехніка»
}

\title{
Удосконалення методичних аспектів обліку, аналізу та контролю запасів підприсмств
}

\begin{abstract}
У роботі обтрунтовано, щзо запаси є фундаментом розвитку підприємств будь-якого виду господарської діяльності. Доведено, що належним чином врегульована термінологія $i$ нормативно-правова база, правильна організація та якісне методичне забезпечення бухгалтерського обліку, аналізу та контролю запасів забезпечать достовірне оприбуткування та списання даних об'єктів на виробництво готової продукції (надання послуг), ефективне управління оборотними активами та дозволять виявляти резерви збільшення віддачі від виробничих запасів. Запропоновано методичний підхід до ведення обліку використання запасів на зазначені изілі підприємства, через операційну та інвестиційну діяльність, а також алгоритм відображення господарських операцій в автоматизованій інформаційній системі рахунків бухгалтерського обліку руху запасів підприємства, щзо дасть можливість більш повно, 3 належним ступенем деталізації обліковувати та аналізувати обсяги запасів, щзо отримані та фактично використані на господарську діяльність підприємства. Удосконалено методичні аспекти аналізу запасів, щзо дозволяють більш прозоро $i$ достовірно відображати та контролювати цільове використання й рух запасів, очінювати ефективність їх використання на підприємствах. Розроблені рекомендації з удосконалення процедури контролю запасів сприятимуть достовірному та повному відображенню їх в обліку та дієвому контролю за надходженням, рухом та списанням у виробництво, що дозволить зменшити витрати підприємства та підвищити прозорість й ефективність господарських операцій із запасами.
\end{abstract}

Ключові слова: облік; аналіз; контроль; запаси; ефективність; автоматизована інформаційна система.

Актуальність теми. Для ефективної роботи будь-якого підприємства потрібно залучати значні ресурси у вигляді таких оборотних активів, як запаси, що будуть спрямовуватися на ефективне здійснення господарської діяльності підприємств, виробництво готової продукції або надання послуг. Вплив низки чинників зовнішнього ринкового середовища накладає свій відбиток на посилення вимог до якісних та вартісних властивостей продукції (послуг), яких можливо досягти тільки через ефективний облік, аналіз та контроль запасів. Особливої актуальності проблема обліку, аналізу та контролю запасів набуває в умовах відчутних несприятливих кон'юнктурних коливань на вітчизняному і міжнародних ринках, а також у кризових умовах господарювання, через військово-політичну нестабільність та світову пандемію COVID-19. Постає завдання ефективного ведення обліку, аналізу та контролю надходження, використання та вибуття запасів, оскільки чинна нормативно-правова база обліку в Україні не дає можливості чітко та прозоро здійснювати формування обліково-контрольної інформації про надходження, використання та вибуття запасів, тому доцільно розглянути зазначену проблематику й запропонувати шляхи вдосконалення.

Аналіз останніх досліджень і публікацій. Методично-організаційним питанням бухгалтерського обліку, аналізу та контролю запасів присвячено наукові праці багатьох українських та зарубіжних вчених. Зокрема, вагомий внесок у методологію, методику й організацію обліку, аналізу та контролю запасів зробили: М.І. Бондарь, С.Ф. Голов, Д.О. Грицишен, В.М. Диба, В.В. Свдокимов, В.М. Жук, 3.В. Задорожний, Л.М. Кіндрацька, Г.Г. Кирейцев, Я.Д. Крупка, М.В. Кужельний, Ю.А. Кузьмінський, С.Ф. Легенчук, В.С. Лень, О.А. Петрик, М.С. Пушкар, В.В. Сопко, Н.М. Ткаченко, М.Г. Чумаченко та ін. Серед зарубіжних авторів заслуговують на увагу праці Х.Андерсона, Г.Александера, С.Барнеса, Дж.Бейлі, П.Бетге, Г.Бірмана, М.А. Вахрушиної, Г.Велша, Р.Г. Еклеса, П.І. Камишанова, Н.А. Каморджанової, Р.Каплана, В.В. Ковальова, Д.Колдуелла, Н.А. Литневої, Л.И. Малявкиної, Т.В. Федорової, М.Ю. Медведєва, Б.Нідлза, В.Д. Новодворского, В.Ф. Палія, С.В. Панкова, В.Е. Рибалкіна, Ф.Роберта, О.В. Рожнової, Я.В. Соколова, М.Фрідмана, Р.Холта, У.Шарпа, С.Шмідта, Р.Шортріджа та інших, в яких висвітлено різні аспекти бухгалтерського обліку, аналізу та контролю запасів підприємств. Огляд літературних джерел дозволив констатувати, що питання, пов'язані зі створенням єдиної систематизованої методики обліку, аналізу та контролю запасів, залишаються у дискусійній площині.

У публікаціях останніх років пропонуються різні методичні підходи до вибору найефективнішого для підприємств методу списання запасів $[1 ; 2 ; 5]$. Проте їх об’єднує бажання звести до мінімуму витрати,

(C) Я.О. Ізмайлов, С.В. Свірко, 2021 
зумовлені необхідністю відшкодування вартості затрачених на запаси ресурсів. Як національними, так i міжнародними стандартами бухгалтерського обліку регламентовано порядок відображення в обліку запасів підприємств. У той же час бухгалтери-науковці намагаються запропонувати чіткий i систематизований порядок та власне бачення можливості формування інформації про запаси на рахунках бухгалтерського обліку. Отже, на підприємствах України потребують детального розгляду проблеми ефективного використання та прозорого обліку, аналізу і контролю запасів.

Метою статті є узагальнення проблем і розробка пропозицій щодо удосконалення бухгалтерського обліку, аналізу та контролю для ефективного здійснення господарських операцій із запасами підприємств.

Викладення основного матеріалу та результати дослідження. Виробничі запаси є найважливішим елементом виробничого процесу на підприємстві, предметами праці, які є основою для виробництва готової продукції та повністю переносять свою вартість на вироблену продукцію. Для ефективного управління запасами на підприємстві необхідна інформація про їх склад, кількість і вартість, яка потрібна для організації обліку запасів підприємства, забезпечення відповідного контролю за їх збереженням на всіх етапах руху запасів сировинних ресурсів, а також для прийняття своєчасних управлінських рішень. Згідно 3 національними та міжнародними стандартами [3; 4], запаси - це активи, що утримуються для подальшого продажу (розподілу, передачі) за умов звичайної господарської діяльності; перебувають у процесі виробництва з метою подальшого продажу продукту виробництва; існують у формі основних чи допоміжних матеріалів для споживання під час виробництва продукції, виконання робіт та надання послуг, а також управління підприємством. Запаси визнаються активом у системі бухгалтерського обліку, якщо існує ймовірність того, що підприємство отримає в майбутньому економічні вигоди, пов'язані з їх використанням, та їх вартість може бути достовірно визначена.

Класифікацію та склад запасів відповідно до пункту 6 П(С)БО 9 «Запаси» [4] наведено у таблиці 1.

Класифікація та склад запасів відповідно до П(С)БО 9 «Запаси» [4]

Таблиия 1

\begin{tabular}{|c|c|c|}
\hline $\begin{array}{l}\text { № } \\
\text { 3/II }\end{array}$ & Вид запасів & Характеристика виду \\
\hline 1 & Виробничі запаси & $\begin{array}{l}\text { Використовуються безпосередньо у виробництві продукції (робіт, послуг), } \\
\text { обслуговування та адміністративному управлінні, включають в себе сировину, основні й } \\
\text { допоміжні матеріали, комплектуючі вироби та інші матеріальні цінності }\end{array}$ \\
\hline 2 & Незавершене виробництво & $\begin{array}{l}\text { Являє собою незавершене виробництво у вигляді необроблених і не складних до кінця } \\
\text { деталей, вузлів, виробів та технологічних процесів. При виконанні робіт (послуг), } \\
\text { включають витрати, щодо яких не визнано доходу }\end{array}$ \\
\hline 3 & Готова продукція & $\begin{array}{l}\text { Продукція, що призначена для продажу і відповідає технічним та якісним } \\
\text { характеристикам, що передбачені договором або іншим нормативно-правовим актом }\end{array}$ \\
\hline 4 & Товари & $\begin{array}{l}\text { Матеріальні цінності, що придбані (отримані) та зберігаються підприємством } 3 \text { метою } \\
\text { подальшого продажу }\end{array}$ \\
\hline 5 & Оборотні МШП & $\begin{array}{l}\text { Предмети, що використовуються протягом не більше одного року або нормального } \\
\text { операційного циклу, якщо він триває понад один рік }\end{array}$ \\
\hline 6 & Поточні біологічні активи & Належать до складу запасів за умови, що оцінюються відповідно до П(С)БО 9 «Запаси» \\
\hline
\end{tabular}

При надходженні запаси оцінюються за їх первісною вартістю, яка відповідно до П(С)БО 9 «Запаси» формується залежно від того, яким шляхом надійшли запаси на підприємство. Крім випадків придбання запасів за плату, можуть використовуватися й інші варіанти їх отримання.

Від правильно організованого документування господарських засобів залежить правильність списання вартості запасів на виробництво, оцінка незавершеного виробництва, відображення у звітності. Структура документообігу має бути такою, щоб забезпечити вчасне надходження необхідної інформації як для обліку, так і для контролю й оперативного управління рухом матеріальних запасів.

Таким чином, необхідно забезпечити чіткий контроль за їх наявністю, надходженням і вибуттям, не допускати можливостей для змішування кількості та вартості різних номенклатур, щоб не створювати умов для пересортування та нестач одних матеріалів за рахунок покриття надлишками інших. Місця зберігання товарно-матеріальних цінностей мають бути належно підготовленими і надійними, щоб виключити псування чи крадіжки матеріалів. Кожне 3 них (склад, комора тощо) повинні мати відповідний шифр (номер), який обов’язково вказують у всіх первинних документах.

Для будь-яких підприємств ефективне та раціональне використання запасів набуває важливого значення в процесі пошуку шляхів зниження собівартості продукції, а також збільшення обсягів виробництва, тому особливого значення набуває визначення основних напрямів економії сировинних ресурсів. Вивчення й аналіз практики роботи промислових підприємств дає змогу визначити такі напрями потенційної економії запасів: скорочення виробничих відходів через застосування нових видів матеріалів; використання вторинних ресурсів; зниження матеріаломісткості через застосування ресурсозберігаючої техніки, впровадження безвідходних технологій; збільшення виходу готової продукції шляхом впровадження й використання науково обгрунтованих норм витрачання сировини на виробництво продукції та поліпшення iї якості. При цьому слід зазначити, що оскільки структура витрат 
на виробництво промислової продукції характеризується великою часткою матеріальних витрат, то спостерігається необгрунтоване співвідношення між часом знаходження обігових коштів у запасах і у виробництві. Водночас збільшення обігових коштів за рахунок кредитів призводить до зростання собівартості продукції та цін, зниження рівня конкурентоспроможності готової продукції.

Для ефективного ведення обліку запасів на підприємствах запропоновано інформаційну модель алгоритму автоматизованого процесу обліку запасів через бухгалтерське моделювання (рис. 1).

Алгоритм автоматизованого процесу обліку господарських операцій із запасами

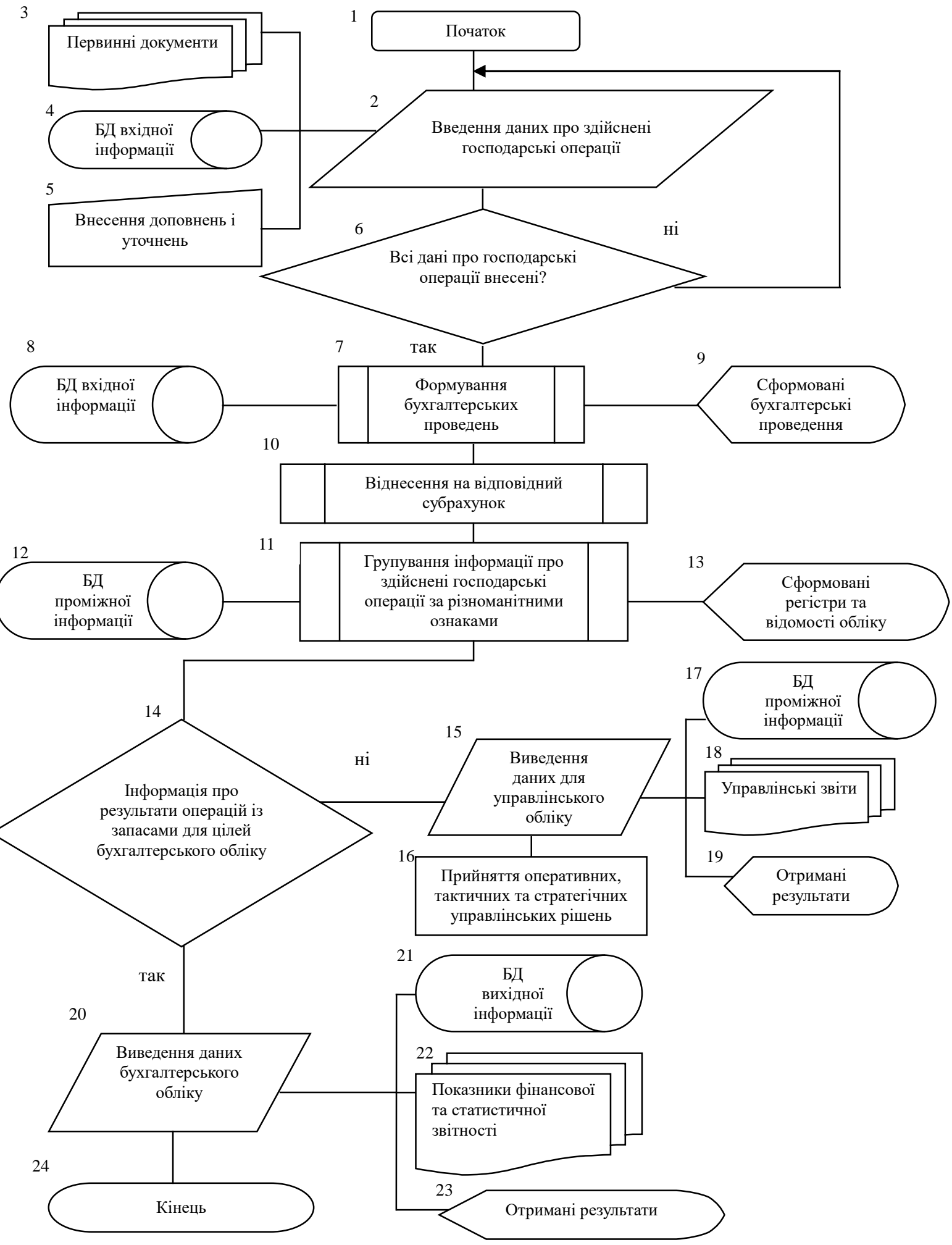

Рис. 1. Алгоритм автоматизованого процесу обліку запасів підприємства (складено авторами) 
Прийняття оперативних, тактичних та стратегічних управлінських рішень із операцій з запасами підприємства стає більш швидким та обгрунтованим. Формування узгоджених потоків інформації забезпечить одночасне задоволення потреби підприємства в належним чином контрольованій системі бухгалтерського та управлінського обліку запасів та в достовірній звітності.

Для спрощення контролю й аналізу складського обліку запасів потрібно:

1) розробити чіткий реєстр документів, який би давав можливість отримати список введених первинних документів за певний період та по будь-якому складу (підзвітній особі);

2) розробити спрощену оборотно-сальдову відомість за товарами на складах та за контрагентами;

3) розробити акт звірки розрахунків з контрагентам;

4) розробити систему контролю наявності необхідної кількості запасів на складах підприємства, що дасть можливість формувати звіт про недостатню кількість запасів для безперебійного випуску продукції.

Запаси у виробничому процесі використовуються за таким порядком, який зазначений на рисунку 2.

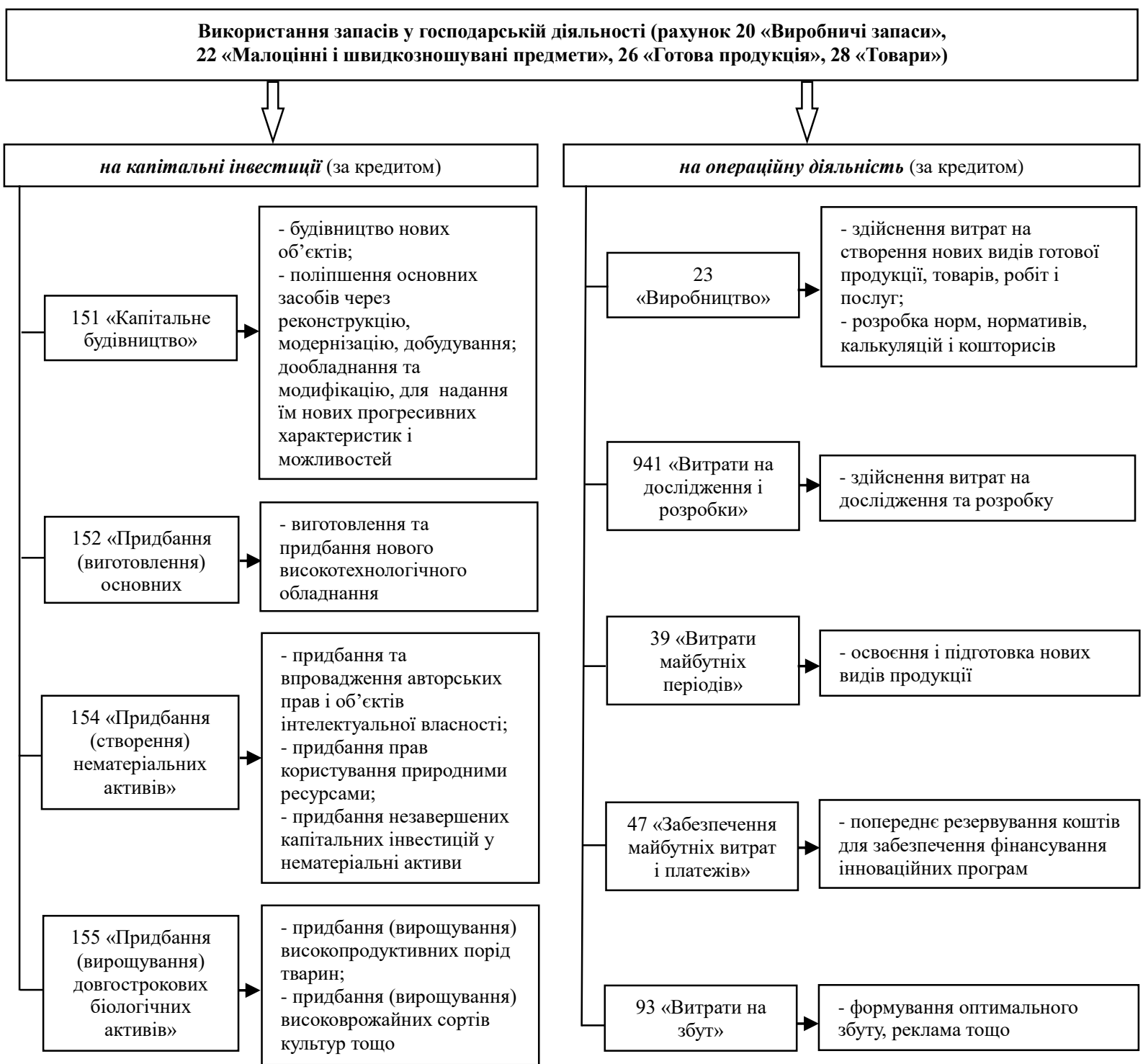

Рис. 2. Порядок відображення в обліку використання запасів на інвестиційну та операційну діяльність підприємства

Використання на практиці запропонованої кореспонденції рахунків, через інвестиційну та операційну діяльність, дасть змогу раціонально організувати цю ділянку обліку запасів через зведення до мінімуму можливості здійснення помилкових записів та полегшення визначення кореспонденції рахунків за типовими господарськими операціями.

Оскільки запаси проходять багато стадій обробки, то вони є важливим і складним об'єктом обліку та контролю. 
Удосконалення процедур контролю запасів необхідне для того, щоб:

1) попередити виникнення помилок і зловживань із запасами;

2) визначити слабкі місця в організації менеджменту запасів;

3) усунути можливі недоліки під час використання запасів;

4) надати пропозиції та провести управлінські консультації, щодо ефективного використання запасів та впливу на фінансові показники діяльності підприємства.

Для ефективного здійснення контролю запасів необхідно особливу увагу приділити перевірці: витрат на зберігання запасів; витрат на транспортування запасів; якості запасів; цін та систем знижок, які пропонують постачальники; потреби підприємства в запасах; повноти відпуску запасів у виробництво; отримання норм використання запасів на виготовлення продукції; витрат на замовлення запасів; витрат від псування запасів; складання плану постачання запасів; витрат на брак у виробництві; наявності страхових запасів; рівня оперативного управління запасами за кожним виробничим переділом; періодичності проведення інвентаризацій залежно від виду запасу.

Для ефективного проведення господарських операцій із запасами підприємствам рекомендовано комплексно застосовувати такі розрахунково-аналітичні методи:

- економічного аналізу операцій із запасами;

- статистичні і техніко-економічні розрахунки обігу запасів на підприємстві;

- аналітичного групування запасів;

- аналізу щоденної або поопераційної зміни залишків запасів;

- оцінки прогнозного стану надходження та використання запасів;

- інші аналітично-прогнозні методи залежно від цільового спрямування запасів.

До заключного етапу контролю, що відчутно впливають на ефективність операцій із запасами підприємств, рекомендовано зараховувати:

- виявлення i врахування допустимих i критичних відхилень від накресленої стратегії i запланованих показників руху запасів;

- встановлення вірогідності не тільки даних обліку і звітності, але й результатів проведеного аналізу показників витрачання, продуктивності та ефективності запасів;

- створення аналітично визначених підстав для захисту майнових і фінансових інтересів господарюючих суб'єктів;

запасів та ін.

Отже, ефективний контроль запасів дає можливість попередити виникнення помилок і зловживань в операціях з запасами, прибрати слабкі місця в організації управління запасами, проводити управлінські консультації щодо ефективного використання запасів та їх впливу на фінансові показники діяльності.

Висновки та напрями подальших досліджень. У період економічної кризи і обмежених ресурсів підприємств важливого значення набуває активний пошук можливостей ефективного управління запасами. Методики ведення обліку, аналізу та контролю придбання, руху та використання джерел надходження, руху та використання запасів недостатньо урегульовані в чинній національній та міжнародній нормативно-правовій базі.

Запропоновано методичний підхід до ведення обліку використання запасів на зазначені цілі підприємства через операційну та інвестиційну діяльність. Використання запропонованого підходу надасть можливість більш повно, з належним ступенем деталізації, обліковувати та аналізувати обсяги запасів, що отримані та фактично використані на господарську діяльність підприємства.

Представлено алгоритм відображення господарських операцій в автоматизованій інформаційній системі рахунків бухгалтерського обліку руху запасів підприємства.

Запропоновано методичні аспекти аналізу запасів, які дозволяють прозоро і достовірно відображати та контролювати цільове використання та рух запасів, оцінювати ефективність їх використання на підприємствах. Методичні засади удосконалення процедури контролю запасів дозволяють посилити контроль за рухом запасів на підприємстві.

Розглянуті обліково-аналітичні та контрольні проблеми та запропоновані рекомендації щодо їх вирішення створюють базу для продовження досліджень у напрямі вдосконалення методології, методики та організації бухгалтерського обліку, аналізу і контролю запасів підприємств.

\section{Список використаної літератури:}

1. Бойцова М. Усе про облік запасів / М.Бойцова, О.Маханько, Я.Клиженко. - Харків : Фактор, 2014. - 160 с

2. Максименко І.Я. Особливості бухгалтерського обліку товарних запасів в системі управління торгівельним підприємством / I.Я. Максименко // Economics and finance. - 2016. - № 9. - С. 228-230.

3. Міжнародний стандарт бухгалтерського обліку 2 «Запаси» [Електронний ресурс]. - Режим доступу: https://zakon.rada.gov.ua/laws/show/929_021\#Text. 
4. Положення (стандарт) бухгалтерського обліку 9 «Запаси» : Наказ Міністерства Фінансів України від 20 жовтня 1999 р. № 246 [Електронний ресурс]. - Режим доступу : https://zakon.rada.gov.ua/laws/show/z0751-99.

5. Шум М.А. Особливості обліку та аналізу виробничих запасів на підприємствах України в сучасних умовах / М.А. Шум, К.С. Гулько // Науковий вісник Ужгородського національного університету. - 2017. - № 4. C. 166-169.

\section{References:}

1. Bojcova, M., Mahan'ko, O. and Klyzhenko, Ja. (2014), Use pro oblik zapasiv, Faktor, Harkiv, 160 p.

2. Maksymenko, I.Ja. (2016), «Features of inventory accounting in the trading enterprise management system», Economics and finance, No. 9, pp. 228-230, [Online], available at: http://conferencii.com/files/archive/2016-09.pdf

3. International Accounting Standard 2 «Current assets», [Online], available at: https://zakon.rada.gov.ua/laws/show/929_021\#Text

4. Ministry of Finance of Ukraine (1999), «Accounting Standard 9 Current assets», Nakaz vid 20 zhovtnja 1999 r., No. 246, [Online], available at: https://zakon.rada.gov.ua/laws/show/z0751-99

5. Shum, M.A. and Gul'ko, K.S. (2017), «Features of accounting and analysis of inventories at Ukrainian enterprises in modern conditions», Naukovyj visnyk Uzhgorods'kogo nacional'nogo universytetu, No. 4, pp. 166-169.

Ізмайлов Ярослав Олексійович - доктор економічних наук, професор кафедри податкової політики Університету державної фіскальної служби України (м. Ірпінь).

https://orcid.org/0000-0003-4853-205X.

Наукові інтереси:

- оподаткування;

- бухгалтерський облік та аналіз.

E-mail: izmyar@ukr.net.

Свірко Світлана Володимирівна - доктор економічних наук, професор кафедри економічної безпеки, публічного управління та адміністрування Державного університету «Житомирська політехніка».

Наукові інтереси:

- бухгалтерський облік в секторі загального державного управління;

- організація бухгалтерського обліку;

- бюджетна система.

E-mail: svs3@ukr.net. 